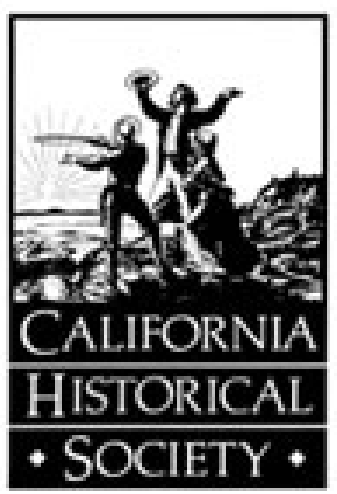

The Evolution of Political Practices in Mexican Alta California and the Rise of the Diputados Author(s): Emmanuelle Perez

Source: California History, Vol. 91, No. 1 (Spring 2014), pp. 72-73

Published by: University of California Press in association with the California Historical Society Stable URL: http://www.jstor.org/stable/10.1525/ch.2014.91.1.72

Accessed: 10/05/2014 16:43

Your use of the JSTOR archive indicates your acceptance of the Terms \& Conditions of Use, available at http://www.jstor.org/page/info/about/policies/terms.jsp

JSTOR is a not-for-profit service that helps scholars, researchers, and students discover, use, and build upon a wide range of content in a trusted digital archive. We use information technology and tools to increase productivity and facilitate new forms of scholarship. For more information about JSTOR, please contact support@ jstor.org.

University of California Press and California Historical Society are collaborating with JSTOR to digitize, preserve and extend access to California History. 


\section{The Evolution of Political Practices in Mexican Alta California and the Rise of the Diputados}

$\mid$ ISTORIANS HAVE often portrayed the political history of Mexican California as a kind of comic opera, featuring a cast of venal Californios and Mexican-appointed officials engaged in sporadic battles over land and the control of Indian labor. But this interpretation takes for granted the existence of "Californios" without probing the origin of that social category, and it fails to consider the roiling changes in Spanish political culture that emerged during the period I808-I82I. Most significantly, historians have consistently underestimated the critical role played by the diputación and the diputados in the revolutions of the era.

The diputación - a committee of seven men indirectly elected biannually-was an outgrowth of the small councils emerging in the provinces of Spain after the French invasion of 1808 , and it was institutionalized by the constitutional assembly of I8I2 in Cadiz. Historian Nettie Lee Benson has argued that though the diputación was relatively weak in Europe, Spaniards in Mexico used it to great avail. My own research bears out Benson's findings, in the new context of the Mexican republic, but also, my local and bottom-up approach illuminates how the use of the diputación in the provinces was negotiated on the ground. Moreover, I pick up the story where Benson left it, when in the I82os diputaciones in other provinces gave way to legislatures but California had a diputación for the first time. In fact, it was the organization of a diputación in I822 in California that facilitated Mexicans' grasp of political power, including supervision of the missions (one of the official attributions of the diputación in America) and some control over their lands. A close reading of primary documents at the Bancroft Library at UC Berkeley,

California History, Vol. 91, Number 1, pp. 72-73. ISSN0162-2897, electronic ISSN 2327-1485. (c) 2014 by the Regents of the University of California. All rights reserved. Please direct all requests for permission to photocopy or reproduce article content through the University of California Press's Rights and Permissions website, http://www.ucpressjournals.com/ reprintlnfo.asp. DOI: 10.1525/CH.2014.91.1.72. 
including minutes of the meetings of the diputación, political manifestos, and private correspondence, demonstrate that Californios increasingly regarded the diputación as a reflection of the will of the people.

As early as I823, Governor Argüello used the diputación to assert his power against the will of the missionaries. In a letter he sent to the president of the Franciscans in California, he ordered the move of a mission, not because it had already been decided by the missionaries' hierarchy, but because the diputación approved it. He adds: "the political authority may not be mocked." In I829, a rival of the governor, heading a mutiny in Monterey, wrote a manifesto where he emphasized the rights of the people to be represented by a diputación (although one was already meeting) and asked for the resignation of the governor, his temporary replacement to be appointed by the diputación. ${ }^{2}$ At the same time, the governor convened a meeting of the diputación which confirmed its support of him. In I832, after a revolution lead by the former governor against the new one, the diputación reiterated its claim to be the body responsible for appointing a new temporary governor. ${ }^{3}$

The rise of the diputación and the diputados was hence the consequence of various causes: the will of the Mexican government to promote a civil elite that would be more loyal than the missionaries to the new state, the rivalry between Mexican civil servants who needed local support, the proselytism of radical politicians who wanted to enroll Californians in their reform plans for Mexico and finally the ambition of the young Californians. It was in the name of the diputación that Alvarado declared the independence of California in I836. His official claim was federalism, a translation of the Californians' desire to have equal rights and achieve self-rule into a national context. The opponents of the revolutions did not oppose this vision of the diputación, but the legality of its actions. Lacking a constitution to sort out political disputes unequivocally, political rivals resorted to popular mobilization for bloodless military campaigns, a means of supplying a visible expression of the "will of the people" that the elections to the diputación seemed to fail to achieve. Oftentimes, this tactic did not work either, and each party ruled a half of the Territory until an external arbitrator-a new governor or an emissary from Mexico-would give legitimacy to a ruler. Consequently, the most stable periods of Mexican California were the times when a governor, legitimated by Mexico, ruled with the diputación.

In a nutshell, politics in Mexican Alta California can be best understood by realizing that the region faced the same crisis of legitimacy as the rest of the former Spanish Empire in the same period. The case of Alta California confirms the role of the diputaciones in shaping political practices in Spanish America, albeit with some lag, and illustrates the problem of political representation after Independence. It also sheds new light on political affiliations in Mexico, in particular the adoption of federalism in the Provinces.

\section{NOTES}

I. Governor Luis Argüello to Mariano Payeras, president of the missions, I7 September I823, Monterey, Bancroft Library, Departmental Records, I, C-A 46, p. 43.

2. Manifesto of the Solis revolt, signed by Joaquin Solis, Mariano Peguero, Andres de Leon, Petronilo Rios, Jose de la Torre; probable author: Jose-Maria de Herrera, comisario subalterno (finance official), I5 November I829, Monterey. Source: Bancroft Library, Departmental State Papers, Benicia, Military, C-A I9 pp. 153-4, vol. 70, pp. 27-28.

3. Minutes of the diputación, II January I832, Los Angeles. Source: Bancroft Library, Legislative records, I, C-A 59, pp. I $84-185$. 